\title{
INTERPRETATION OF SUTAN TAKDIR ALISJAHBANA'S NOVEL "DIAN YANG TAK KUNJUNG PADAM"
}

\author{
Jafar Lantowa \\ Faculty of Literature and Culture, State University of Gorontalo, Indonesia \\ Jalan Jenderal Sudirman No. 6 Gorontalo, Indonesia \\ Corresponding Author: jafar.lantowa@ung.ac.id
}

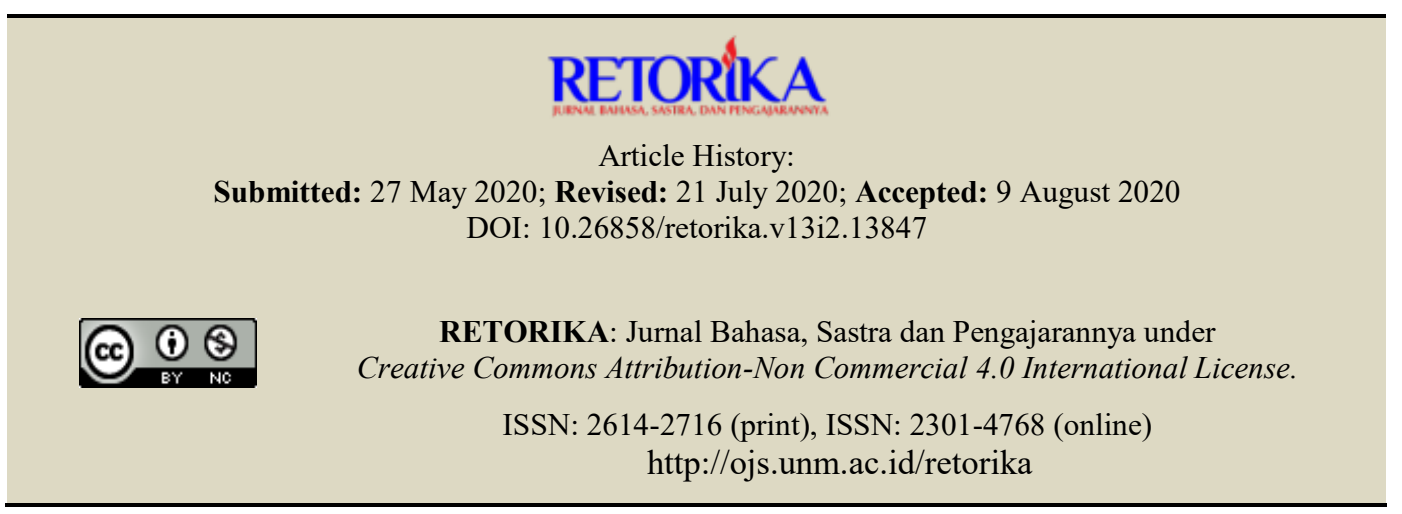

\begin{abstract}
This study aims to uncover the implicit meaning contained in Sutan Takdir Alisjahbana's novel Dian yang Tak Kunjung Padam through Yuri Lotman's semiotic approach. The first edition of this novel was published in 2007 by Dian Rakyat with a total of 156 pages. The method used in this study was qualitative method. The data were collected from two sources, namely intra textual data which was Sutan Takdir Alisjahbana's novel Dian yang Tak Kunjung Padam and extra textual data which were correlated to the novel. The results showed that the structure of the novel was formed by semantic units in the form of binary oppositions which were equivalent to each other. The semantic units led to an archiseme which was a spatial form of the aristocracy view of life namely longing vs. hate. In the novel, the aristocracy view of life in Palembang society was placed in opposition to the structure of another view of life, the proletariat. The later was evaluated based on the aristocracy. The codes of aristocracy and proletariat in the text of the novel were related to those outside the text. The main semantic units of Palembang aristocracy are bilateral vs. personal and wealth vs. love.
\end{abstract}

Keywords: binary opposition, literary, novel, semantics field

Literary work is a reflection of thoughts, feelings, and desires of the author through language. The language itself is not just any language, but a specific one that is a language that contains signs or semiotics (Endraswara, 2008). Novel is a literary work that uses language as a sign system so that it contains hidden meanings that must be revealed by the reader. Novel con- tains a complex and unique structure and expresses something that tends to be indirect. This is what makes novel difficult for readers to interpret. Therefore, the analysis of a novel requires an explanation accompanied by evidence and results related to the analysis. In literature, analysis means giving consideration to elaborating the elements contained in a literary work. In other 
words, analyzing a novel is understanding a literary work well and explaining it to readers so that they get a complete understanding (Ardienie et al., 2017).

Dian yang Tak Kunjung Padam is a novel that is full of sign systems. Written by Sutan Takdir Alisjahbana, this novel tells the issue of love in relation to customs that are held tightly by parents. In other words, this novel still revolves around the conflict between the young and the old. The love between Yasin and Molek physically failed, but spiritually they won. This novel is written in languages that cannot be interpreted directly because of the signs that are very much contained in it.

This story is quite interesting but there are still some parts of the story that need to be interpreted through semiotics in order to be fully understood. Therefore, this novel needs to be studied through the theory of semiotics. The emphasis of semiotic theory in relation to literary works is the understanding of the meaning of literary works through signs. This is based on the fact that language is a sign system as well as literary media. The entire text of a literary work are signs that need to be interpreted to get a better understanding. Literary text as a whole is a sign that contains indirect expressions that need to be interpreted by the reader (Lantowa, Nila Mega Marahayu, M.K 2017).

According to Preminger, semiotics is the science of signs. Semiotics studies social-cultural phenomena, including literature as a sign system. The aspects of sign in semiotics are divided into two distinct components, namely signifier and signified. Signifier is a formal form of the sign, such as language or letters, while signified are the meaning or sense of the sign itself (Yuniasti et al., 2018). Semiotic analysis is a study which states that a literary work (novel) is a sign that has meaning. In a novel, the slightest sign certainly has meaning (Aini, 2013). Semiotic analysis of fictional stories that must be carried out is to treat all structures as signs. The analyst must always ask whether the character, setting, plot, or storytelling in a novel is a sign or not. After seeing the elements as signs, the signs are then described based on the context (Mushodiq, 2018). Novels as literary texts contain signs to be interpreted through semiotic analysis. As stated by Piliang (2004), text analysis is one of the branches of the semiotics of text which specifically examines text as a 'product of language use' in the form of a collection or combination of signs, especially those concerning sign systems (syntactic/ paradigmatic), the level of signs (denotation/ connotation), the correlation between the signs (metaphor/ metonym), the content of the myth, and the ideology behind the story. This ideology contains moral that must be understood by readers through texts, because literary texts generally contain a variety of positive messages. Literature is usually interpreted as text with aesthetic language and good content. Aesthetic language means that it can impress and entertain readers. Good content means useful or contains moral values (Sunahrowi \& Restu N, 2018).

Yuri Lotman's theory of semiotic (19771990) was selected in studying the novel Dian yang Tak Kunjung Padam because it makes it easier to understand the linguistic signs that exist in the novel so that the meaning contained therein will be more clearly understood by the reader. Lotman's theory of semiotics cannot be separated from the Tartu-Moscow Semiotic School where Lotman becomes an important figure there. This group, consisting of academics from various disciplines, holds regular seminars in the 60s-70s. Some of Lotman's thoughts such as the Secondary Modeling System and the "world model" are elaborated from the ideas developed in this group. Lotman (1977: 8-9) states that each system aims to establish communication between two individuals namely the sender and receiver or more can be defined as language and each language uses a sign which is its particular vocabulary. He divides language into three kinds, namely natural language (everyday language), artificial language such as the language of science and road signs, and secondary language or secondary modeling system which is a communication structure built as a superstructure on a natural language. Literary works, paintings, music, and myths are examples of secondary modeling systems. Lotman contrasts the term secondary modeling system with natural language as the primary modeling system. The secondary modeling system is a structure based on natural language. As a structure placed on natural language, the system has additional ideological, ethical, aesthetic, and other secondary structures. In everyday language, the language system is ignored: we tend to accept the meaning of words and arrange them into sentences according to the conventional rules of grammar. However, at the secondary level, automation collapses. The 
expectations of the reader become uncertain, and the reader will only be able to find the secondary system through careful reading (Lotman in Maier: 318-319).

Based on the explanation that has been stated previously, the author conducted a semiotic study on Sutan Takdir Alisjahbana's novel Dian Yang Tak Kunjung Padam. In this study, the author analyzes the modeling system and the semiosphere in the novel by using Yuri Lotman's theory of semiotic which aims to reveal the implicit meaning contained therein.

There are several studies related to this study, including Khairussibyan (2014) in his thesis entitled "New Tradition: Lotman's Semiotic Study and Deconstruction of Putu Wijaya's novel Putri". This study found that the codes of modernism and traditionalism in the text of the novel $\mathrm{Pu}$ tri are connected with the codes of Balinese modernism and traditionalism outside the text. The correlation is in the form of similarities and differences between semantic units in the text and semantic units outside the text. The main semantic units of Balinese traditionalism are humans vs. nature, groups vs. individuals, subtle vs. rough, and sacred vs. less sacred. Whereas modernism, which is also the world view of this novel, is characterized by subjectivity, rationality, distance, materialism, progressiveness, realism, and so on. This simi-larity relationship is called as aesthetic equality (identity). Extra textual correlation as aesthetic difference arises in the process of translation. Balinese traditionalism embodied in the text is not presented as the persona of Balinese traditionalism understood, but rather represented or interpreted based on the thought of modernism. This finding shows that this novel not only reflects reality, but also reflects the author's awareness.

Yulianti (2014), in her study entitled "Gadjah Mada's Romanticism: The Study of Lotman's Cultural Semiotics" examines romanticism that is modeled as a plot in the Langit Kresna Hariadi's novel Gajah Mada. Yuri Lotman's Cultural Semiotics is considered suitable to answer the problem; explaining the story line in a novel is a part of cultural semiotics. The concepts of cultural semiotics used in this study include: secondary modeling systems, a message, a model, aesthetic production, semiosphere, and narrative text structure. These concepts then describe the strong romantic syndrome content in the novel.
Simply put, Yuri Lotman's theory of cultural semiotics asserts that literary works are secondary modeling systems that rely on langu-age as the primary modeling system. Literary works are not on a literal level, so special mecha-nisms are needed to understand them. Lotman calls this mechanism as the semiosphere. This research concludes that through Lotman's theory of cultural semiotics and the mechanism of the semiosphere, the novel Gajah Mada is a message, a model, and an aesthetic production. A message; the novel shows that literary works contain messages in the form of information to be conveyed to readers; A model; if the text is a model, then the novel is a secondary modeling system; Aesthetic Production; when the artwork must deal with replicas of reality, and those replicas must be hidden in a semiotic situation as a possibility.

Based on several studies presented earlier, the author comes to an initial conclusion that studies that uses Lotman's theory of semiotics in analyzing a novel has not been carried out much. In addition, since the novel as a literary work has a sign system that expresses something indirectly, the meaning contained therein is also not expressed explicitly, but realized through signs. Therefore, this study seeks to reveal the meaning contained in the text of Sutan Takdir Alisjahbana's novel Dian Yang Tak Kunjung Padam through the semiotic theory of Yuri Lotman.

Lotman (1977: 35-36) divides the transcoding/recoding process into two parts. The first process is internal recoding, which is when an element is codified back into another element and correspondence correlations take place in which an element in the system itself appears to be equivalent to other elements in the same system. Lotman also calls it the relational meaning that arises when an element is expressed through other elements of the same system.

The second process is external recoding, which is the equivalent process of an element with other elements from outside the system. Romanticism literature is an example of a secondary modeling system that is dominated by internal recoding while realism is dominated by external recoding. The meaning that is formed in the internal recoding process is called syntagma-tic while the meaning formed in the external recoding is called paradigmatic. Recoding, orga-nically, is related to the equivalence problem. The 
semantic equivalence of units in an artistic text is manifested in a different way: it is based on the juxtaposition of lexical units which in primary structures (linguistics) may be considered as unequal (Lotman, 1977: 46). The equivalence of nonequivalent elements encourages us to assume that signs which have different meanings at the linguistic level, have the same meaning at the secondary system level (Lotman, 1977: 47). The meaning arises from equalizing different elements or establishing equality among several primary semantic systems that are not alike or the same. Repetition of recoding gives the possibility to construct a semantic core that is common to various systems, something that is understood as meaning beyond the boundaries of the sign structure and entering the world of objects (Lotman, 1977: 38). To bring out the meaning, artworks are broken down into a semantic field, a series of concepts of resistance which eventually merges into a final antithesis called "archiseme" (Lotman in Maier, 1982: 320).

The idea of semiosphere itself was put forward by Lotman in his book entitled Universe of The Mind (1990). Lotman describes the semiosphere as a semiotic space without which no language could function. Binaryism and asymmetry are the basic laws that bind all semiotic systems. Binaryism must be understood as a principle that is plural because every new formed language is always separated into binary principles (1990: 124). The most important basic mechanism in semiotics is boundary. This boundary allows agents in a semiotic space to distinguish between "our space", "our own", "cultured" and "safe" and their opponents: "their space", "others'", "enemies", "dangerous", and "chaotic". Every culture divides the world into internal space and external space. How this binary division is interpreted depends on the cultural typology (Lotman, 1990: 131).

Boundary is a central point in the process of semiotization. It is ambivalent: it separates and unites at the same time. It is always the boundary of something so that it belongs to both cultural boundaries, two adjoining semiosphere. Boundary is a mechanism for translating texts from a foreign semiotics into "our" language, it is a place where what is "external" is transformed into something "internal". It is a filter that turns foreign texts into part of the internal semiosphere by continuing to retain its characteristics (Lotman, 1990: 136-137). This boundary concept determines the position of the persona in a cultural system or artistic text. Persona itself is interpreted by Lotman as a representation of abstract functions, both the functions of agents that break through existing semantic fields and the barriers that try to defend them (Faruk, 2002: 27). Personas who are positioned in the boundary of the semiosphere can represent how two different semiotic spaces interact such as, for instance, when a certain semiotic structure regards an individual as part of a group, but the persona feels himself not to be part of the group. Lotman gives the following example: in Europe before the Renaissance, an individual was punished for the actions of members of his social group, but in the Post-Renaissance period that sort of thing was no longer accepted because the individual was considered autonomous from his social group (1990: 138-139). Based on the type of agent breakthrough on the semantic field, the text is divided into two types namely mythic text and peripheric text. Myth text is a text that describes the structure of the world. Text showing standard, ordered, and constant concepts: correlated concepts showing a social, cosmological, geographical, or world structure representation. On the other hand, peripheric texts are texts that describe places, situations, and human actions in their world. This type of text deviates from the mythic text by destroying the classification of the world into two parts, the order is confounded with a disaster or accident, an anomaly. This type of text aims to question or even undermine a standard invariant scheme through an event or action of a person or agent (Maier, 1982: 321). This division can help us understand whether an author is trying to make a text that represents a standard order or a constant world structure or a text that is trying to question an order.

In his book, Structure of the Artistic Text (1977), Lotman contrasts text with extratext. According to him, the meaning of artwork is distorted for readers who try to understand it by arbitrary and subjective code; the meaning also does not exist for the reader who treats the text by separating it from all extratextual relations. The extratextual bonding of a work can be described as a correlation between the set of standard elements in the text and the set of elements outside the text from which the elements in the text are sorted (Lotman, 1977: 50). The extra text can be the literary tradition of the author, the real situation, and the ideology used as material to 
build a correlation system in his work (Shukman, 1977: 64).

\section{METHOD}

This study employed qualitative methods. Qualitative methods are descriptive and tend to use analysis. Kriyantono (2006) states that qualitative research aims to explain phenomena as deep as possible through deep data collection. This study also used semiotic approach. The semiotic approach departs from the assumption that social phenomena, the society, and culture are signs. This means that the emphasis of the semiotic approach in this study is the understanding of meaning in literary works through signs. The data were sourced from Sutan Takdir Alisjahbana's novel Dian yang Tak Kunjung Padam. The first edition of the novel was published in 2007 by Dian Rakyat with a total of 156 pages.

The method of data collection used was literature study. Data collection was carried out by reading Sutan Takdir Alisjahbana's novel Dian yang Tak Kunjung Padam carefully, directed, and thoroughly. At the time of reading, the author noted the linguistics signs from the text of the story to be interpreted. Data analysis was performed based on Lotman's semiotic method. The data collected came from two sources, namely intratextual data, the novel which was the object of this study, and extratextual data related to the novel. Intratextual data collected are codes that can be used to find answers about the novel modeling system. The whole code in a novel is the compiler of its primary modeling system. But not all the codes in the text were used as data to be analyzed in compiling the novel's secondary modeling system. The data used was in the form of hierarchical events and binary oppositions that supported the archiseme as the highest opposition in the secondary modeling system. The secondary modeling system was then linked to the extratextual system. Thus, intratextual elements and extratextual elements were connected through a secondary modeling system of text that had been identified previously. The correlation was analyzed as part of the aesthetic of differences and similarities. As Lotman said, to produce meaning in a system there must be at least two opposing structures. That is why, the extratextual correla- tion identified in this novel was not only the correlation between intratextual semiosphere and equivalent extratextual semiosphere, but also identified the correlation between intratextual non-systemic elements and equivalent extratextual non-systemic semiosphere. Extratextual correlations at the secondary modeling level targeted not only the ideological level, but also the historical facts and social structures that were identified as part of the material from which the modelling system in the novel was selected.

\section{FINDINGS AND DISCUSSION}

\section{Findings}

\section{The Modelling System of the Novel Dian yang Tak Kunjung Padam}

As a primary modeling structure, the novel Dian Yang Tak Kunjung Padam tells the story in Indonesian about a young man named Yasin. He is an orphan who has a low social standing in the society. In the Gunung Megang area, near the city of Palembang, Yasin lives with his mother. One day, he sailed to Palembang and met a beautiful girl named Molek. The girl is the daughter of a nobleman in Palembang. At that time, Molek was relaxing on the porch of his luxurious house near the river. Apparently, the beauty fell in love at first sight with Yasin. So did Yasin. However, their love could not be realized because of the striking difference in social status between the two. Both Yasin and Molek were both aware of this fact, but their turbulent love ignored that fact. That is why they shed their feelings through a letter in which all the longing they felt flowed. The whole novel talks about how these two characters harbored a burning desire, and how Yasin struggled to be united with Molek.

One day, Yasin was determined to end their romance which was always carried out clandestinely. He was about to propose Molek openly. He then conveyed his intention to his mother and all his relatives. After deliberating, with all their simplicity, they proposed Molek. However, their proposal was rejected by Molek's family because they came from poor hamlet families. They even insulted and insinuated Yasin's family so that the entourage returned home with a pile of shame and resentment. 
Shortly thereafter, the Molek family was visited by Sayid, an elderly merchant of wealthy Arab descent. Molek's materialistic parents immediately decided to accept Sayid's proposal. However, their married life did not bring happiness to Molek because she did not love Sayid. She also knew that the purpose of Sayid marrying her was only because of her father's property.

When he learned that the love of his life was suffering, and also because of his deepening longing, Yasin tried to meet Molek in Palembang disguised as a pineapple trader. However, the meeting turned out to be their last meeting because Molek, who deeply harbored a longing for Yasin, finally passed away. After the death of his lover, Yasin returned to his village. Shortly thereafter, his mother also passed away. All the calamities that befell him made the man chose to live in solitude on the slopes of Mount Semeru and died on the mountain.

At this point, we do not find a comprehensive model of loving relationships that also models the author's awareness. Therefore, we have to move to a higher structure, namely the secondary modeling system.

The novel Dian yang Tak Pernah Padam is actually formed by a plot with a series of events that Yasin tried to do as a hero in the story. The hero tried to cross from one pole to another. Yasin, who was at one pole tried to express his longing through a letter to Molek, the daughter of a wealthy nobleman who was at the other pole. Yasin's longing reaped enormous hatred from both Molek's parents. They did not approve if their daughter is married by a man who is not equal to them.

The semantic field of longing vs. hate is equivalent to the semantic field of rich vs. poor. This opposition shows the inherent and irreversible difference that the rich must marry the rich. This opposition then becomes invariant to the opposition underneath that is happy vs. sad. This novel portrays happiness as destined wealth and sadness as poverty or underestimation. Its equivalence with the archiseme of longing vs. hate is based on the novel's assumption that the rich and poor poles are more appropriate for life purposes than the happy and sad poles because the latter two merely represent the feelings experienced by Molek and Yasin's parents (Alisjahbana, 2007: $88 / 101)$.

In this novel, although the position of rich vs. poor is hierarchical, inter-polar elements are described as being able to enter one another. Rich elements can be in poor elements. Likewise, the poor element often participates in the marriage celebration of the rich, but only as a person who regulates the needs in the kitchen. The process of entering into one another's poles is illustrated by the frequent occurrence of problems where a daughter of a rich person meets someone who is poor without the family's knowledge and then becomes a disgrace in the family.

This phenomenon leads us to a more specific binary opposition namely rich-prosper-ous vs. poor-suffering. Rich-prosperous is when all desires can be fulfilled and all emotions can be channeled at will by having power, while poorsuffering is when living only as a farmer or fisherman.

Other semantic fields are beautiful vs. ugly and mental vs. physical. The equivalence of these two semantic fields is different from the semantic fields mentioned earlier because these two semantic fields are more focused on the effects of the semantic field of rich vs. poor: social class differences that diminish the love of two people. The next semantic field is sincere vs. forced. Molek was finally married to Sayid. Sayid's proposal was accepted by Molek's parents without her knowledge. Yasin let the love of his life marry another man. Even though his heart was broken, he did not want to break ties with Molek because he did not want her to suffer alone. Molek married very forcefully and was not happy with it. Molek who has a beautiful face suddenly becomes ugly. Mental pressure and unremitting longing in Molek's heart made her pale and thin (p. 93). Opposition of women vs. men is also a dominant semantic field. This novel illustrates that in Palembang's social structure, if a girl is proposed by a man who is socially unequal or has a lower social class, the proposal will be rejected. So a man who has nothing like Yasin is surely rejected by Molek's family.

The next semantic field is mother vs. child. In this novel, there are fundamental differences between mothers and the child. The basic element that opposes mother to child is their attitude to hierarchical social structures. The mother sided with the habits of the Palembang people who tried to maintain the hierarchical social structure of the aristocracy, while the child wanted that there is no difference between the social structure of the Palembang people and the Uluan people. There must be a common right and obligation as human 
beings. There is nothing wrong with a poor person marrying a rich person. Molek was always in conflict with her parents but she could not argue too far because she was afraid of her father and mother.

Another important semantic field is the opposition of humble vs. arrogant. Overall, the personas in this novel are divided into these two poles. Another semantic field in this novel is day vs. night. All yearning collided during the day and night. Yasin who missed Molek wanted to marry her but was hindered by differences. All of these semantic fields are centered into a major archiseme, longing vs. hate. This shows that the novel has a Palembang aristocratic worldview in opposition to the proletariat. The semantic fields are arranged as follows.

\section{Table 1. The Semantic Fields}

\begin{tabular}{cll}
\hline No. & \multicolumn{2}{c}{ Oposisi Biner } \\
\hline 1. & Longing & - Hate \\
2. & Rich & - Poor \\
3. & Happy & - Sad \\
4. & Beautiful & - Ugly \\
5. & Mental & - Physical \\
6. & Sincere & - Forced \\
7. & Women & - Men \\
8. & Mother & - Child \\
9. & Humble & - Arrogant \\
10. & Day & - Night \\
\hline
\end{tabular}

All of the semantic field poles on the left are equal to one another, and so are the right poles. However, the correlation between the left and right poles is entirely hierarchical. In other words, in the structure of the novel, the longing pole is higher than the hate pole, the rich pole is higher than the poor pole, and so on.

As Lotman said, the use of pronouns is important in analyzing the author's worldview. The novel Dian yang Tak Kunjung Padam uses the third person singular pronoun "he". The use of these pronouns makes it easy for authors to play the point of view. In this novel the author has the role of the third person omniscient.

Lotman (1977: 266) says that truth does not exist in one point of view but rather in the accumulation of several points of view. In this novel, we can identify the point of view of the people and the author by referring to the quantity and quality of the emerging semantic fields. As stated earlier, the archiseme in this novel is the opposition of longing vs. hate. The archiseme is spread over a number of events that have different semantic fields, but it remains a variant of the semantic field of miss vs. hate.

It was not long after Mrs. Yasin with two
other women and a man came down from
the big house, returned from proposing
Molek. They returned home empty-handed,
because Cek Sitti said bluntly, that her
youngest child could not be handed over to
the Uluan people. Her soul mate must be a
noble like her too (Alisjahbana, 2007: 81).

In the quote above, there are three semantic fields which are equivalent to each other namely the semantic field of longing vs. hate, women vs. men, and rich vs. poor. The first, second, and third semantic fields are formed because Yasin, who attributes himself as part of the longing pole, wanted to marry Molek, the daughter of a nobleman.

Molek's hope of being able to unite with Yasin was only a fantasy because Yasin's proposal was rejected outright by both Molek's parents.

One day, Molek was proposed by Sayid Mustafa, a well-known and wealthy Arab descendant in the city of Palembang. The proposal was received by Raden Mahmud and his wife, because although Sayid Mustafa was not a Palembang aristocrat, his social class did not decrease in their eyes, because he was a descendant of the prophet and came from the Holy Land. As people who firmly hold on to religion, it was felt by them that they were very fortunate to get such a son-in-law, and they also hoped in their hearts to get a blessing from the sacred offspring (Alisjahbana, 2007: 106).

Every day Molek mourned thinking about her unfortunate fate. Why did that damned Arab come propose to her? Instead of having a husband like him, she would rather not be married for the rest of her life. She could not love him, despite how much his wealth was and how sacred his descendants were. All of that was worthless to her, because her heart, her soul, had been handed over to Yasin the Uluan who was seen by his parents as not being human (Alisjahbana, 2007: 107).

The quote explains the semantic field of happy vs. sad. Both Molek's parents were very 
happy to have a son-in-law of Arab descent. But not with Molek. She was so sad, she wanted to reject the proposal, but her lips could not speak in front of his parents. The quote illustrates the sadness that produces the semantic field of beautiful vs. ugly.

Her eyes, immersed in and did not the slightest glow, always looked stunned, like the eyes of someone who was not in her right mind. Her forehead was always wrinkled, imagining the inner suffering that did not come out of his mouth which was almost always closed, tight and strong, so that her lips slumped to the face. Molek, a girl who has always been very charming, has become a woman who is withered and does not shine anymore (Alisjahbana, 2007: 120).

Therefore, the semantic field of beautiful vs. ugly is the change that occurs in Molek who lives her life without any happiness. Her parents only think of wealth without thinking about her happiness. This semantic field is derived from the semantic field of longing vs. hate. Moreover, the semantic field of beautiful vs. ugly also has a derivative that is mental vs. physical, where men-tal is in the form of conflict within a character and physical is the form of the human body that we can see the changes.

Meanwhile, Yasin endlessly stared at her body. She underwent enormous changes, her once beautiful body had been jointed, apparently, because she was so thin. Even so, the shadow of beauty that had been vanished by infinite suffering was still visible. And for Yasin, all these changes could not change his love, just the opposite, because he knew, that his beloved bore all the doomed dooms because of him, because of their unquenchable love (Alisjahbana, 2007: 135).

The previous quote defines the semantic field of mental vs. physical. Yasin always missed Molek, and Molek always held his longing for Yasin so that she slowly became thin. This semantic field of mental vs. physical produces a semantic field derivative of sincere vs. forced, where Yasin learned to sincerely give up Molek to marry someone else, and Molek was forced to marry Sayid only because of her parents.

An obvious equivalence between the semantic fields of mother vs. child are in the section where Yasin expressed his intention to propose
Molek to his mother and got a positive answer. It was different from what Molek experienced. She tried to be honest with his mother but instead considered a family disgrace.

\begin{abstract}
"In that case, whatever you think is fine, because it is clear that you can feel it more than me. But let me remind you that in all your endeavors do not be hasty and take a good care of yourself. And when you have finished your business in Palembang, you must return home as soon as possible, so that I will not worry for long about you". (Alisjahbana, 2007: 46). An answer as well as a message from Ms. Yasin to Yasin.
\end{abstract}

Hearing her daughter's words, Cek Sitti could no longer contain her anger; with a hoarse voice she said, rebuking with anger: "You are going to marry the rotten Ulu. You have really gone crazy. Even just to sweep my house, I don't want to accept Uluan people, let alone to be the husband of...." The old woman's eyes glowed, as if she were about to swallow her. No, she could not accept such a thing. At that time, her love for her daughter vanished, and she no longer thought of the words that came out of her mouth. (Alisjahbana, 2007: 89).

The two quotes above illustrate the semantic field of mother vs. child. The difference only lies in the response of the two mothers. The second quote relates to the semantic field of women vs. men, which is Cek Sitti who was very angry when she found out that Molek loved Yasin who was an Uluan (inland), because the Palembang aristocrats would never approve if their daughter was proposed by someone who was not a nobleman. They would even look down on the man. Semantic field of day vs. night is a time setting that is often used in this novel. In the day time, Yasin sold rubber at the market, while at night Yasin went to get a letter from Molek placed next to where Molek bathed. Yasin and Molek quietly exchanged letters, and Yasin would go to get a reply from Molek at night.

\section{Semiosphere and Semiosphere's Boundary}

Lotman (1977: 8-9) states that each system that aims to establish communication between two sending and receiving individuals or more, can be defined as language and each language uses a sign that is its particular vocabulary. In the novel Dian Yang Tak Kunjung Padam, there is a secondary language built on natural languages 
(Indonesian and Palembang), although the language style is quite difficult to understand because it contains too many figures of speech. This novel also still uses old appellations such as $\mathrm{Ka}$ kanda-Adinda. The characters still send letters to each other and still use a boat as a means of transportation. This novel also uses noble titles in the Palembang sultanate, such as Raden for men and Raden Ayu for women. The title Raden in this novel is attached to Molek's father, Raden Mahmud, which indicates that they are of royal lineage. Yasin and the Molek family are both Palembangese but have different castes. Molek's family is aristocrat and lives in a luxurious house in the city, while Yasin is an Uluan (hinterland) who only relies on rubber and his garden.

These two differences impose limits on the structure of the aristocracy and the structure of the proletariat. Different semiosphere structures make it possible to see different perspectives. The boundary of the semiosphere is the area where problems arise to bring to life the personas of each semiosphere. In this novel, Yasin is presented as the proletariat persona. He feels that he has no difference with Molek because his love is so sacred to her, whereas both Molek's parents consider themselves a semiosphere of aristocrat who do not accept a proletariat son-in-law.

After understanding the structure of the novel and how the personas within it resist, we proceed with further understanding efforts that target the modeling system outside the novel. The link between the selected elements in the text and the set of elements from which the elements in the text are sorted out is what Lotman calls extratextual bonding.

Lotman (1977: 50) states that textual elements located at various hierarchical levels enter into different extra textual relations. At the primary language level, Palembang's natural language elements (aristocratic titles in the Palembang sultanate) have an extra textual correlation with natural language in Palembang outside the present text. Likewise at the secondary language level, the proletariat in the text of the novel has an extra textual correlation with the proletariat outside the present text.

\section{Semiosphere of Palembang Aristocracy}

In this section, identification of correlations between the codes of Palembang aristocracy in the text and outside the text is done back and forth. The focal point of attention is the similarities and differences between elements of the text and elements outside the text.

The events in the novel Dian Yang Tak Padam involving noble personas can lead us to an understanding of the semiosphere of Palembang aristocracy and subsequently bring us to the extra textual relations of the nobility outside the text. The personas of the semiosphere of the Palembang aristocracy are titles that are only used by aristocratic groups, such as Raden and Pesirah for the clan head. The title Raden is attached to Molek's father named Raden Mahmud, and the title Pesirah is attached to Yasin's cousin named Thalib. These titles provide a semiotic space to direct us to elements outside the text that originate from the semiosphere of Palembang aristocracy.

To understand the extratextual elements in the novel Dian yang Tak Kunjung Padam, we refer to the semantic fields that will be described in this section, namely the main semantic fields which contrast between the Palembang aristocracy and the proletariat.

\section{Bilateral and Personal}

Bilateral vs. personal is the main semantic field in Palembang aristocracy. The concepts of bilateral and personal relations are strongly held by the Molek family. The Palembang aristocracy placed bilateral in a higher hierarchical position than the personal. Bilateral is said to be higher because Palembang aristocrats have the principle of kinship (two parties) in which they are more friends with fellow groups. Their kinship results in a bond that is tied to the marriages of their children. However, the pattern of settling after marriage is usually auxorilocal, because new couples usually build their homes near the neighborhood of the women's family. This explanation is also illustrated in this novel, where after marriage Sayid lived in Molek's house.

A mate chosen personally by a child will not be taken for granted by their parents. They will ask various questions related to the descent of the chosen mate. Extratextual in this novel is the fact that it has become a habit in Palembang aristocratic families to record their family tree and pass it on from generation to generation. However, these habits began to diminish in the present, and only a small number of people still care about their family tree. Even many pages of their 
family tree have been damaged or lost somewhere.

This novel is composed from these semantic fields. The noble Molek family acted arrogant to the Yasin family who lived in simplicity. Wealth, title, throne, and power are the most important things for Raden Mahmud and his wife Cek Sitti.

\section{Wealth and Love}

The concepts of wealth and love relationship are firmly held by the Molek family. Having a lot of wealth is everyone's dream and always brings happiness, just as love that always brings happiness and is always coveted by humans.

Palembang aristocracy is part of the wealth. Wealth becomes an important reference point in the behavior of Palembang aristocrats. For them, if the man who come to propose to their daughter is a rich person, then they will be happy and be able to provide good offspring (Alisjahbana, 2007: 106). Cek Sitti, Molek's arrogant mother, sees marrying a fellow nobleman will surely bring happiness and eternal love. In fact, love cannot be bought with money because it is sacred from the heart of every human being.

The extratextual of this novel is that the wealth based relationship as depicted in the novel Dian yang Tak Kunjung Padam, is now slowly disappearing in society. Today, anyone who wants to propose a Palembang girl is permitted on the basis of love, but it must be with the customs of the Palembang people and all their rituals.

Love and wealth are inseparable unity in human being. Both are energies that must and are able to be managed by humans as intelligent beings because in reality, human perfection lies in his mind.

\section{Semiosphere of the Proletariat}

Proletar is the working class that sells services and energies to capital owners. Life in society is always associated with the struggle for social classes. This social class is the cause of prolonged conflict (Karl Marx 1818).

The semiosphere of the proletariat occurred to Yasin who missed the daughter of a nobleman. He thought that his love, longing, and farms were enough to make Molek happy. $\mathrm{He}$ could sell his rubber so he could live with her. Unfortunately, it was different from the mindset of the aristocrats that tried to separate Yasin from Molek because of a very different social status. All Yasin's efforts to propose Molek were in vain. They even once intended to elope but failed. Violence at the aristocratic pole hurt Molek so bad that he chose to leave this world. Molek had no problem with the proletariat status of Yasin because for her, aristocracy was only a bonus in her life. However, it was very different from the arrogance that was inherent in Molek's parents, especially her materialistic mother.

\section{Discussion}

\section{The Modeling System of the Novel Dian Yang Tak Kunjung Padam}

The first page of the novel presents figures of speech that portrays a very simple life. In chapter 2 , this novel depicts a life surrounded by wealth, giving rise to a semantic field of rich vs. poor. The Yasin family who is far from luxury live only by relying on rubber and the family farm.

One day, Yasin went to Palembang to sell his rubber by boating through the Musi River. The cool air of the Musi River made Yasin relax for a moment on his boat near the house of Raden Mahmud. A moment later, his eyes accidentally met the eyes of the youngest daughter of Raden Mahmud named Molek.

That gaze immediately became a promise that their love could not be separated by anyone, even though in reality they were both so much different as the ridge who missed the moon. However, it was all denied by Yasin's desire that his love would definitely be reciprocated. From the beginning, this novel has confirmed the character of the hero, Yasin, as a strong persona of his stand. Since Yasin knew that his love was reciprocated by Molek through a letter, Yasin increasingly established himself in order to marry Molek. With a description of the feelings expressed by Yasin and Molek in the letter, and the expression of Molek's parents' hatred towards those who are not in the same caste with them, Yasin and Molek acted at the longing pole and Molek's parents at the hate pole.

The affirmation of rich vs. poor existed when the Yasin family from Uluan ventured to propose Molek, the daughter of a nobleman in Palembang, while both Molek's parents did not like 
the Uluan people (people living in inland). In primary modeling, this novel only provides a fraction of reality about a hero named Yasin who wants to realize his desire to marry a girl who is beautiful and noble. However, in secondary modeling, this novel is an actualization of a complete meaning system, a reality model that is divided between the author and the reader. The study of the artistic language of artworks not only gives a certain value to aesthetic communication, but also reproduces a universal model in its most common form (Lotman, 1977: 18).

The novel Dian Yang Tak Kunjung Padam as a real model is composed of semantic fields that the hero tries to enter. Some of the semantic fields formed in this novel cone on an arctic or the highest semantic field that is longing vs. hate. As for the other semantic fields such as rich vs. poor, happy vs. sad, beautiful vs. ugly, mental vs. physical, sincere vs. forced, women vs. men, mother vs. child, humble vs. arrogant, and day vs. night, are variants of the invariant of longing vs. hate. Each pole of opposition has the equivalent of the other pole in another semantic field.

\section{Semiosphere and Semiosphere's Boundary}

Semiosphere is a semiotic space needed for the interaction of functions and the existence of language and other sign systems. This space is able to encompass and explain each interaction. Semiosphere is seen as a cultural text that is both structured and abstract. This makes the meaning that appears becomes difficult to predict. Cultural context is very influential in the meaning process. It takes place in the semiosphere and surrounds it at the same time. For example, meanings that are closely related to certain myths, religions, or beliefs. In general, it will be difficult to understand the results of these forms of semiosphere. On this basis, it is necessary to trace the construction that exists in the semiosphere and then reconstruct the signs that appear related to the semiosphere. This is intended to find a system that regulates either in general or specifically. Reconstructing a cultural code does not mean explaining all the cultural phenomena, but rather choosing and then explaining why there is a certain culture that has produced these phenomena (Lotman, 1990: x). Semiosphere is a semiotic unit which is the smallest functional mechanism, not something isolated, but the whole space of cultural semiosis which is always questioned (Putra, 2019: 38-39). The obvious discourse is love and hate which enter one another's space because of the opposition between the semiosphere of Palembang aristocracy and the semiosphere of the proletariat. In this novel, Ya$\sin$, as a proletarian persona, felt that there was no difference between Molek and himself because his love was so sacred to Molek. However, both Molek's parents considered themselves to be the semiosphere of Palembang aristocracy that did not accept the proletariat son-in-law. This study found that the codes of aristocracy and proletariat in the text of the novel Dian yang Tak Kunjung Padam were related to the codes of aristocracy and proletariat outside the text. The main semantic units of Palembang aristocracy are bilateral vs. personal, and wealth vs. love, while the proletariat in this novel is characterized by poverty, farms, and trade.

The dominance of the aesthetic difference makes this novel interesting. However, since the habits of the aristocrats in this novel are different from today's life, this novel can become a fairy tale or a myth because of Molek's words that her holy spirit will wait for Yasin in another world.

\section{CONCLUSION}

Dian Yang Tak Kunjung Padam by Sutan Takdir Alisjahbana is a novel that illustrates a never ending inner conflict. A love story that ends in eternal separation. This study found that the structure of this novel was formed by semantic units in form of binary oppositions which are equivalent to each other. The semantic units are centered on one archiseme namely longing vs. hate. The archiseme is a spatial form of aristocratic view of life. Thus, the Palembang aristocracy's view of life was placed in an oppositional relationship with another structure of view of life, namely the proletariat. The latter is evaluated on the basis of aristocracy.

Settings or spatial structures, plot, persona, and character are formed based on the view of life of Palembang aristocracy and proletariat. Semantic units such as longing vs. hate that build the structure of the novel include rich vs. poor, happy vs. sad, beautiful vs. ugly, mental vs. physical, sincere vs. forced, women vs. men, humble vs. arrogant, mother vs. child, and day vs. night, which are variants of the invariant of longing vs. 
hate. There are also other variants such as richprosperous vs. poor-suffering.

Based on the attitude or response to the spatial structure, the personas in the novel Dian yang Tak Kunjung Padam are divided into two, the persona of the semiosphere of Palembang aristocracy and the persona of the semiosphere of the proletariat. The personas of the semiosphere of Palembang aristocracy include Raden and Pesirah (clan chiefs). Raden is attached to Molek's father, Raden Mahmud, and Pesirah is attached to Yasin's cousin named Thalib. They are the ones who reject the unequal love. While

\section{REFERENCES}

Aini, A. N. (2013). Analisis Semiotik terhadap Novel Laskar Pelangi Karya Andrea Hirata sebagai Alternatif Bahan Pengajaran Sastra di SMA. Jurnal Ilmiah Nosi, 1 (2): 80-86.

Ardienie, S.(...) Analisis Semiotik Sistem Tanda pada Novel ORB Karya Galang Lufityanto. Jurnal Ilmiah Nosi, 5 (5): 1-14.

Endraswara, S. (2008). Metodologi Penelitian Sastra. Yogyakarta: Media Pressindo.

Faruk. (2001). Beyond Imagination. Yogyakarta: Gama Media.

Hoed, H. B. (2011). Semiotik dan Dinamika Sosial Budaya. Jakarta: Komunitas Bambu.

Irwanto, D., dkk. (2010). Iliran dan Uluan: Dinamika dan Dikotomi Sejarah Kultural Palembang. Yogyakarta: Eja Publisher.

Khairussibyan, M. (2014). Tradisi Baru: Kajian Semiotika Lotman dan Dekontruksi Atas Novel Putri Karya Putu Wijaya. Tesis. Yogyakarta: Magister Ilmu Sastra FIB UGM.

Lantowa, J., Nila M. M. (2017). Semiotika: Teori, Metode, dan Penerapannya dalam Penelitian Sastra.Yogyakarta: Deepublish.

Luxemburg, J., et al. (1989). Pengantar Ilmu Sastra. Jakarta: Gramedia.

Mushodiq, M. A. (2018). Tanda Peircean dan Maknanya dalam Unsur Intrinsik Cerpen 'Indama Ya'Ti Al-Masa' Karya Naguib Mahfouz. LiNGUA: Jurnal Ilmu Bahasa dan Sastra, 13 (1): 46-59.

Piliang, Y. A. (2004). Semiotika Teks :Sebuah Pende- the persona of the semiosphere of the proletariat are those who try to hold on to the unity of their sacred love, who try to seek the blessing of the semiosphere of aristocracy, namely Yasin. This action is carried out by people who are on the boundary of the semiosphere, a pair of hero and heroine. Yasin as a hero in this novel is not only trying to fight his longing for Molek at all times, but also always looking for ways so that his love for Molek can be approved by both of Molek's parents even though he is not a nobleman.

katan Analisis Teks. MediaTor:Jurnal Komunikasi, 5 (2): 189-198.

Putra, J. N. I. (2019). Tanda Budaya dalam Cerpen Filosofi Kopi Karya Dee Lestari Tinjauan Semiotika Budaya Juri Lotman. Jurnal Skripta, 5 (1): 32-40).

Shukman, A. (1977). Literature and Semiotics: A Study of the Writings of Yu. M. Lotman. Amsterdam: North-Holland Publishing Company.

Siegers, R. T. (2000). The Evaluation of Literary Teks (Evaluasi Teks Sastra). Diterjemahkan oleh Suminto A. Sayuti. Yogyakarta: Adicita Dee.

Sobur, A. (2006). Semiotika Komunikasi. Bandung: Remaja Rosdakarya

Sunahrowi, dan \& Marita, Restu N. 2018. Hymné À La Beauté Karya Charles Baudelaire: Kajian Semiotika Puisi Riffaterre. RETORIKA: Jurnal Bahasa, Sastra, dan Pengajarannya, 11 (1): 77-87).

Alisjahbana, S. T. (2007). Dian Yang Tak Kunjung Padam, Jakarta: Dian Rakyat.

Yulianti, Y. (2014). Romantisisme Gajah Mada: Kajian Semiotika Budaya Lotman. Tesis. Yogyakarta: Magister Ilmu Sastra FIB UGM.

Wellek, R. \& Warren, A. (1956). Theory of Literature. New York: A Harvest Book Harcourt, Brace and Company

Yuniasti, H. (2019). 'Potret Diri' melalui Semiotika Riffaterre: Puisi Jahwasang Karya Yoon Dongju. Jurnal Bahasa, Sastra, Seni, dan Pengajarannya, 47 (2): 106-114. 